\title{
Effect of bee pollination on yield and yield components of field bean (Vicia faba L.)
}

\author{
ANNA-LIISA VARIS \& RAIJA BRAX ${ }^{1}$ \\ Department of Agricultural and Forest Zoology, University of Helsinki, \\ SF-00710 Helsinki, Finland
}

\begin{abstract}
The effect of bees on the yield of field bean (Vicia faba L.) was studied in cage experiments in southern Finland during two successive years. Comparisons were made between field cages with and without honeybees and open-pollinated uncaged controls. Effect of shading was also considered.

The yield in open plots, which were freely visited by pollinators, was considerably greater than in plots from which the insects were excluded. Freely visited plants and plants caged with bees produced about twice as many seeds as plants caged without bees, and the number of seeds per pod was also higher. The plants were tallest in cages without bees. In open plots, $44 \%$ of the bee visitors were honeybees, $56 \%$ being bumblebees.

The higher number of seeds obtained with honeybee pollination indicates that honeybees are able to pollinate the field bean flowers in the conditions prevalent in Finland. - It is concluded that there is little value in introducing bee colonies in small field bean areas and places where bumblebees are fairly abundant. Honeybees may improve the yield in larger fields, where natural pollinators are often scarce.
\end{abstract}

Index words: bee pollination, Vicia faba, honeybees, bumblebees

\section{Introduction}

Field bean has been cultivated in Finland since the 16th century. At the moment its acreage is rather small, being only 70 to 100 hectares. In the recent years there has, however, been increasing interest in cultivating

' Present address: Vaasankatu 14 B 32, SF-00500 Helsinki, Finland the field bean, and it has been taken into the breeding programme (Hovinen 1988). The protein content of the seeds is relatively high, as is the content of lysine, an amino acid, which makes beans suitable for use in diets based mainly on lysine-deficient cereals (Clarke 1970). The field bean may also be useful as a break crop in farms with inten- 
sive cereal production. It could be more widely grown as an important source of homeproduced feed protein if its yields were more stable. The variations in yield are great (e.g. VARIS et al. 1982), which may partly be caused by weather conditions and susceptibility to pests and diseases; yield variations may also result from problems with pollination (e.g. LAwes 1974).

Considerable yield increases caused by honeybees have been reported for the field bean (e.g. Scriven et al. 1961, Poulsen 1974), a plant where both self-pollination and crosspollination occur. The increases in yield, however, vary considerably in studies performed under different conditions, and according to Free \& Williams (1977), the pollination requirements are well worth studying for each type of conditions. The aim of the present study was to clarify the effect of pollination by bees on the podding and yield of field bean in southern Finland.

\section{Materials and methods}

Field trials were carried out on the Viikki Experimental Farm of the University of Helsinki $\left(61^{\circ} 12^{\prime} N\right)$ in 1979 and 1980 . Spring sown bean (cf. Mikko, Hankkija, Finland) was used with rows $12.5 \mathrm{~cm}$ apart.

The treatments were:

1. Plants covered by a cage containing honeybee colony

2. Plants covered by a cage to exclude the insects

3. Plants not caged

4. Plants covered by a cage with only two walls (in 1980 only)

Nylon screen cages with an area of $2 \mathrm{~m} \times$ $2 \mathrm{~m}$ and a height of $1.5 \mathrm{~m}$ were placed over the plants just before flowering. Randomized plot design with three replicates was used. The distance between plots was $4 \mathrm{~m}$. The total field bean area was 800 square metres in 1979 and 500 square metres in 1980 . In 1980 a field bean area of 3500 square metres was situated at $50 \mathrm{~m}$ distance from the experimental field.

In 1980 a further treatment was added in which the plants were covered by a cage with only two walls. The purpose of this treatment was to clarify the role of the possible shading effect of the cages.

For yield data, the total bean yields of the plots were weighed, and the numbers of pods and seeds per pod were counted from $4 \times 5$ plants per plot. To obtain the percentage of flowers producing pods, the number of flowers in these plants was counted twice a fortnight during the flowering period in 1979, but because this work was highly time-consuming, in 1980 the counting was based on the scores left by the flowers, and it was done immediately after the harvest. The yield data were analysed by the analysis of variance.

In 1980 the numbers of honeybees and bumblebees were calculated three times per day (between 9 and 10 a.m., 12 and 1 p.m., 3 and 4 p.m.) per 2 square metres in the centre of the field bean area. Only "positive"' pollinators which visited the front of the flower for nectar and pollen were counted.

\section{Results}

Seed yields. In 1979 the yields from noncaged plots averaged $3600 \mathrm{~kg}$ per hectare and in 1980 , when the yield ripened too early because of the drought, only $400 \mathrm{~kg}$ per hectare. In both years the highest yields were obtained from the non-caged plots. In spite of the great differences in yield, the tendency between the plots caged with bees and those caged without bees, in favour of the former, was the same in both years (Table 1). In the second year the yield in shading cages was $68 \%$ of that of the non-caged plots. The seed weight of field bean grown in the open field was greatest.

Number of seeds per plant was considerably smaller in plots without pollinators than in open plots or in plots with bees. In shaded plots the number of seeds per plant was about the same as in the open field.

Number of seeds per pod was lowest in the plots where the pollinators were excluded.

Percentage of flowers producing pods. Most of the flowers did not produce pods. The 
Table 1. Effect of bees on the yield and growth of field bean.

\begin{tabular}{|c|c|c|c|c|c|}
\hline & & \multicolumn{2}{|c|}{ Plants caged } & \multicolumn{2}{|c|}{ Plants in } \\
\hline & & $\begin{array}{c}\text { without } \\
\text { bees }\end{array}$ & $\begin{array}{l}\text { with } \\
\text { bees }\end{array}$ & $\begin{array}{l}\text { open } \\
\text { plots }\end{array}$ & $\begin{array}{c}\text { shaded } \\
\text { plots }\end{array}$ \\
\hline $\begin{array}{l}\text { Seed yield } \\
\mathrm{kg} / \mathrm{ha}\end{array}$ & $\begin{array}{l}\text { 1st year } \\
\text { 2nd year } \\
\text { mean }\end{array}$ & $\begin{array}{r}1623.8 \\
46.8 \\
835.3^{a}\end{array}$ & $\begin{array}{r}1875.0 \\
114.8 \\
994.9^{a}\end{array}$ & $\begin{array}{r}3567.0 \\
399.2 \\
1983.3^{b}\end{array}$ & 273.0 \\
\hline $\begin{array}{l}1000 \text { seed } \\
\text { weight } \mathrm{g}\end{array}$ & $\begin{array}{l}\text { 1st year } \\
\text { 2nd year }\end{array}$ & $\begin{array}{r}224.5^{\mathrm{a}} \\
51.6^{\mathrm{a}}\end{array}$ & $\begin{array}{r}201.6^{\mathrm{a}} \\
45.4^{\mathrm{a}}\end{array}$ & $\begin{array}{r}421.0^{\mathrm{b}} \\
64.3^{\mathrm{a}}\end{array}$ & 63.6 \\
\hline $\begin{array}{l}\text { No. of pods } \\
\text { per plant }\end{array}$ & $\begin{array}{l}\text { 1st year } \\
\text { 2nd year } \\
\text { mean }\end{array}$ & $\begin{array}{l}5.8 \\
1.4 \\
3.6^{\mathrm{a}}\end{array}$ & $\begin{array}{l}7.2 \\
3.4 \\
5.3^{\mathrm{a}}\end{array}$ & $\begin{array}{l}9.7 \\
4.1 \\
6.9^{a}\end{array}$ & 3.5 \\
\hline $\begin{array}{l}\text { No. of seeds } \\
\text { per plant }\end{array}$ & $\begin{array}{l}\text { 1st year } \\
\text { 2nd year } \\
\text { mean }\end{array}$ & $\begin{array}{c}16.2 \\
3.1 \\
9.7^{\mathrm{a}}\end{array}$ & $\begin{array}{r}28.8 \\
9.9 \\
19.6^{\mathrm{b}}\end{array}$ & $\begin{array}{l}28.9 \\
12.0 \\
20.5^{b}\end{array}$ & 12.1 \\
\hline $\begin{array}{l}\text { No. of seeds } \\
\text { per pod }\end{array}$ & $\begin{array}{l}\text { 1st year } \\
\text { 2nd year } \\
\text { mean }\end{array}$ & $\begin{array}{l}2.7 \\
2.3 \\
2.5^{a}\end{array}$ & $\begin{array}{l}3.2 \\
2.9 \\
3.0^{b}\end{array}$ & $\begin{array}{l}3.0 \\
2.9 \\
3.0^{\mathrm{b}}\end{array}$ & 3.4 \\
\hline $\begin{array}{l}\% \text { of flowers } \\
\text { producing } \\
\text { pods }\end{array}$ & $\begin{array}{l}\text { 1st year } \\
\text { 2nd year } \\
\text { mean }\end{array}$ & $\begin{array}{l}16.3 \\
17.6 \\
17.0^{\mathrm{a}}\end{array}$ & $\begin{array}{l}18.6 \\
32.0 \\
25.3^{a}\end{array}$ & $\begin{array}{l}22.8 \\
39.4 \\
31.1^{\mathrm{a}}\end{array}$ & 38.0 \\
\hline $\begin{array}{l}\text { Height of } \\
\text { plants } \mathrm{cm}\end{array}$ & $\begin{array}{l}\text { 1st year } \\
\text { 2nd year } \\
\text { mean }\end{array}$ & $\begin{array}{r}116.1 \\
54.2 \\
85.2^{\mathrm{a}}\end{array}$ & $\begin{array}{c}108.7 \\
58.4 \\
83.6^{a}\end{array}$ & $\begin{array}{l}97.5 \\
51.5 \\
74.5^{b}\end{array}$ & 53.2 \\
\hline
\end{tabular}

Means followed by different letters within the same row are significantly different $(\mathrm{P}<0.05$, Duncans multiple range test). Interaction treatments $\times$ years was significant $(\mathrm{P}<0.05)$ only in 1000 seed weight.

pod-flower ratio was lowest in plots where the pollinators were excluded. In open plots, which correspond to the normal growing conditions, the proportion of pods/flowers was $23 \%$ in 1979 and $39 \%$ in 1980.

Height of the plants. In non-caged plots the plants were significantly shorter than in other treatments.

Pollinators. $43.6 \%$ of the bee pollinators in the open plots were honeybees, the rest bumblebees. Long-tongued species, $B$. subterraneus (L.) and B. hortorum (L.) and to some extent also $B$. lucorum (L.), were the visitors.

\section{Discussion}

The yield in open plots freely visited by pollinators was more than twice as high as in plots from which insects were excluded. The level of bumblebee and honeybee activity in these plots was rather high to affect the yield through effective cross-pollination. The yield in plots caged with bees was higher than the yield in plots from which the insects were excluded. The difference was, however, not significant, which indicates that it is difficult to arrange natural conditions for bees in cages and to maintain the optimal amount of bees in them. The results are in accordance with those of FrEE (1966), who blaimed the detrimental effect of caging, which " is likely to minimize any differences in seed production,"' and suggested that the beneficial effect of bee pollination would probably be greater than implied by the results. The shading effect of the cages alone does not explain the differences, because the yield in shading cages was more than twice as great as in the cages with bees and several times greater than in the cages from which the pollinators were excluded.

The total area of field bean may also affect 
the results. In our experiment the total area of field bean was rather small allowing the bumblebees, as more effective pollinators, to achieve adequate pollination in the open plots. In large field bean areas the number of wild bees would most likely be smaller which would emphasize the role of honeybees. BOND and POPE (1974) noticed that crossing decreased as field size increased. In eastern England the critical size above which the number of wild insects would not be sufficient was, however, as high as between 12 and 32 ha.

There are different opinions about the effect of plant density on the crossing frequency of field bean (e.g. FyFe 1954, Homola 1973). In any case, the highest yields from springsown field bean are generally obtained with narrow rows (12-18 cm) (e.g. McEven 1973, BengtSSON and BingeFors 1975).

\section{References}

Bengtsson, A. \& Bingefors, S. 1975. Odlingstekniska försök med åkerböna. Inverkan av såtid, radavstånd och utsädesmängd. Summary: Agronomic experiments with field beans. Effect of sowing date, row spacing and seed rate. Lantbr.högsk. Medd. A 229: $1-27$.

Bond, D.A. \& Pope, M. 1974. Factors affecting the proportion of cross-bred and self-bred seed obtained from field bean (Vicia faha L.) crops. J. Agric. Sci. Camb. 83: 343-351.

Clarke, H.E. 1970. The evaluation of the field bean (Vicia faba Linn.). Proc. Nutr. Soc. 29: 64-73.

FREE, J.B. 1966. The pollination requirements of broad beans and field beans. J. Agric. Sci. 66: 395-397.

- \& Williams, I.H. 1977. The pollination of crops by bees. Apimondia. 14 p. Bucharest.

FYFE, J.L. 1954. Plant breeding studies in leguminous forage crops. II. Further observations on natural cross-breeding in winter beans. J. Agric. Sci. Camb. 45: $141-147$.

Homola, I. 1973. The present stage of heterosis breeding
The number of seeds per plant was the same in the bee cages as in the open plots, and it was twice as high as in plots without pollinators. The greater number of seeds per pod in bee cages and open plots is in accordance with the results of FreE (1966) and Poulsen (1974).

Although the honeybee pollination resulted in higher numbers of pods and seeds than did self-pollination, the larger seed size in the latter compensated the difference in yield weight.

The shading decreased the number of pods, and the honeybee pollination resulted in the same amount of pods as did free access in the shaded plots. The number of seeds per pod was increased by the shading. The shelter against the sun and wind offered by the cage walls may have been favourable for the pollinating insects.

in broad bean (Vicia faba L. var. equina). Genetika a Slechteni 9: 67-74.

Hovinen, S. 1988. Breeding of field bean (Vicia faba L.) with early maturity. J. Agric. Sci. Finl. 60: 260-267.

LAwES, D.A. 1974. Field beans: improving yield and reliability. Span 17: 21-23.

McEven, J. 1973. The effects of growth regulators, seed rates and row spacings on field beans (Vicia faba L.). J. Agric. Sci. Camb. 80: 37-42.

Poulsen, M.H. 1974. Pollination, seed setting, crossfertilization and inbreeding in Vicia faba L. Zeitschr. Pfl.züchtung 74: 97-118.

Scriven, W.A., Cooper, B.A. \& Allen, H. 1961. Pollination of field beans. Outlook Agric. 3: 69-75.

Varis, E., Hovinen, S., Kansanen, P. \& Kauppila, R. 1982. Legumes in Finnish agriculture. Finnish National Fund for Research Development. Nitrogen project. Rep. 1. p. 219-231. Helsinki.

Ms received August 21, 1989 


\section{SELOSTUS}

\section{Mehiläisten merkitys härkäpavun pölyttäjinä}

\author{
Anna-Liisa Varis ja Raija Brax
}

Helsingin yliopisto, Maatalous- ja

metsäeläintieteen laitos, $00710 \mathrm{Helsinki}$

Helsingin yliopiston Viikin koetilalla järjestetyissä kokeissa pyrittiin selvittämảän, mikă merkitys hyönteispölytyksellä on härkäpavun sadonmuodostukseen sekä missä mäărin mehiläisten suorittama pölytys vaikuttaa härkäpavun satoon.

Osalle koeruuduista asetettiin juuri ennen kukintaa häkit, joiden sisälle vietiin pieni mehiläisyhteiskunta, osalle hăkit, joissa pölyttăjăhyönteisiă ei ollut. Lisăksi kokeessa oli avoin koeruutu, johon pölyttäjähyönteiset pääsivăt vapaasti, sekă toisena koevuonna molemmista păistăăn avoin varjostushăkki. Koe järjestettiin vuosina 1979 ja 1980. Ensimmäisenă vuotena kasvu oli hyvä. Toisena vuotena kasvit tuleentuivat kuivuuden johdosta liian aikaisin ja sato jäi pieneksi.

Mehilăispölytys lisäsi hărkäpavun siemensatoa $19 \%$ itsepölytykseen verrattuna, mutta ero ei ollut merkitsevä $95 \%$ :n luotettavuudella. Sen sijaan avoin pölytys, jossa sekă mehiläiset että kimalaiset voivat vapaasti toimia pö-

' Nykyinen osoite: Vaasankatu 14 B 32, 00500 Helsinki lyttäjinä, lisäsi satoa merkitsevästi pelkkäăn mehiläispölytykseen ja itsepölytykseen verrattuna. Siementen lukumäără kasvia kohti oli sekă mehilaaishăkkien ettă avointen ruutujen kasveissa likimain kaksinkertainen verrattuina pölyttäjiltă suljettuihin häkkeihin ja myös siementen lukumaaărä palkoa kohti oli suurempi. Avoin pölytys vastasi lähinnả tăydellistă pölytystã, koska hărkăpapuala oli suhteellisen pieni ja pölyttăjien mäără riittävă. Kasvin korkeus, joka kuvastaa vegetatiivisen kehityksen nopeutta, oli ensimmäisenă vuotena suurin pölyttäjiltả eristetyssä häkissä osoittaen itsepölytykseen pakotetun kasvin pyrkimystả pitkittaaă vegetatiivista kasvua.

Mehiläispölytyksellă saatu siementen suurempi lukumäärä osoittaa, ettă mehilăiset pystyvăt Suomen oloissakin pölyttämään härkäpavun kukan. Saadun kokemuksen perusteella mehiläisten käyttöă voi suositella laajoilla hărkăpapualoilla, joilla on puutetta kimalaisista. 